\title{
Effect of air pollutants on some heavy metals and biochemical constituents of leaves of some plants at Bangalore city: A case study
}

\section{B. T. Manjunath*}

Department of Botany, Bharathiar University, Coimbatore- 641046 (TamilNadu), India Jayaram Reddy

Department of Botany, St. Joseph's Post Graduate Centre, Bengaluru-560027 (Karnataka), India

*Corresponding author. E-mail: manjunath.bt@christuniversity.in

\section{Abstract}

Rapid urbanization in India has necessitated for undertaking remedial measures to minimize the alarming air pollution levels and consequent health effects. Promotion of vegetation that is tolerant to air pollutants is considered as an ecological sustainable strategy for mitigation of ill effects of particulate matters. In this regard the levels of four heavy metals viz. zinc $(\mathrm{Zn})$, lead $(\mathrm{Pb})$, copper $(\mathrm{Cu})$ and chromium $(\mathrm{Cr})$ and its effects on antioxidants levels (Catalase activity), phytochemicals (Protein, Proline, Gallic acid) and lipid peroxidation were studied in six commonly growing plants- O. sanctum, L. aspera, L.camara, V. rosea, $B$. spectabilis and $R$. communis from polluted (Zone I) and unpolluted (Zone 2) environments of Bangalore. Mean levels of heavy metals were comparatively higher in plants from polluted environments. Mean levels of Total protein $(6.57 \pm 1.71 \mathrm{v} / \mathrm{s} 8.35 \pm 1.27$ $\mathrm{mg} / \mathrm{g})$, gallic acid $(15.79 \pm 22.51 \mathrm{v} / \mathrm{s} 22.95 \pm 25.66 \mathrm{mg} / \mathrm{g})$ and Catalase activity $(66.72 \pm 17.95 \mathrm{v} / \mathrm{s} 78.94 \pm 15.24 \mathrm{mU} / \mathrm{g})$ was comparatively decreased in plants from polluted sites compared to non polluted control sites. Mean Proline $(3.11 \pm 0.46 \mathrm{v} / \mathrm{s} 2.63 \pm 0.66$ $\mathrm{mg} / \mathrm{g})$ and Malonaldehyde $(19.07 \pm 13.86 \mathrm{v} / \mathrm{s} 16.62 \pm 13.49 \mathrm{nmol} / \mathrm{g})$ levels, indicators of oxidative stress, was comparatively increased in plants from polluted sites. Positive correlation of lipid peroxidation in leaves was observed with heavy metals copper $(r=0.961$, $P<0.005$ in control sites; $r=0.881, P<0.05$ in polluted sites) and chromium $(r=0.792$ in control sites; $r=0.758$ in polluted sites). $Z n$ levels showed statistically significant $(P<0.05)$ positive correlation with gallic acid content in plant leaves $(r=0.871$ in control sites: $r=$ 0.937 in polluted sites). Total protein content showed significant negative correlation $(\mathrm{P}<0.005)$ with $\mathrm{Cu}(\mathrm{r}=-0.846)$ and $\mathrm{Cr}(\mathrm{r}=-0.943)$ in control sites, but non-significant negative correlation in plants from polluted sites. The study revealed that plants responded to stress induced by air pollutants and produced phenolic compounds to tolerate and mitigate the oxidative stress.

Keywords: Air pollution, Catalase, Heavy metal, Lipid peroxidation, Proline

\section{Article Info}

DOI:10.31018/jans.v11i1.1961 Received: December 7, 2018 Revised: January 28, 2019 Accepted: February 3, 2019

\section{How to Cite}

Manjunath, B.T. and Reddy, J. (2019). Effect of air pollutants on some heavy metals and biochemical constituents of leaves of some plants at Bangalore city: a case study. Journal of Applied and Natural Science, 11(1):66 - 75

\section{INTRODUCTION}

Air pollution due to increased anthropogenic activities associated with rapid urbanization, automotive exhaust is known to adversely affect the vegetation and ecosystem. Increased exposure to air pollution has been associated with numerous respiratory diseases, cardiovascular diseases and mortality in China and India. Worldwide 7 million deaths have been reported due to air pollution associated health effects (WHO, 2016). In India, all the metropolitan cities have air pollution levels that exceeded the mean limits for annual exposure as per WHO air quality guidelines (WHO 2006). In cities like Bangalore, due to rapid increase in vehicular traffic without any adequate mass transportation system, there is an increase in the levels of air pollutants that at present needs ecologically sustainable strategies to reduce the pollutants.

WHO has recommended various regulatory and policy measures like bringing down vehicular emission and increasing green space in urban environments for bringing down the air pollutant levels worldwide. Vegetation, particularly leaf is known to cover an estimated area of $4.0 \times 10^{8} \mathrm{sq}$ $\mathrm{km}$ on the earth which supports up to $10^{26}$ bacterial cells has the ability to adsorb or absorb air pollutants in the tissue or transform pollutants into lesser toxic or nontoxic metabolites (Wei et al., 2017). Phytoremediation of pollutants from air, soil and water has been given importance as they offer low cost, environmental friendly and ecologically sustainable process for the developing coun- 
tries. Effective application of phytoremediation technologies requires studies on air pollutants, plant habitat and effects of pollutants on the vegetation for selection of right plant (Woo et al., 2007).

Air pollution can affect plants directly on leaves or indirectly through alteration in physicochemical changes in soil. Common deleterious effects of pollutants on sensitive plants includes leaf injury, stomatal damage, premature senescence, decreased photosynthetic activity, damage to membrane permeability leading to reduced growth. Plants have various phytochemicals viz - glutathione, vitamin $\mathrm{C}$, polyphenols, flavanoids and antioxidant enzymes such as peroxidases, catalase, superoxide dismutase to protect against oxidative stress induced by pollutants. Prolonged exposure to air pollutants causes oxidative stress by production of reactive oxygen species (ROS) leading to depletion of cellular lipids and peroxidation of polyunsaturated fatty acid that determines the growth and survival of vegetation (Woo et al., 2007; Tiwari 2006).

Plants have evolved mechanisms to prevent accumulation of toxic substances through regulation of stomatal response. Plants when exposed to pollutants constantly absorb, accumulate and integrate these pollutants into their systems. Plants in response to pollutants have been reported to adapt by altering the biochemical process or accumulation of certain metabolites that protect from oxidative stress (Sayantan and Shardendu, 2017). Proline levels has been shown to be important indicator of plant exposure to stress from various pollutants such as $\mathrm{SO}_{2}$, heavy metals and salt (Woodward and Bennett, 2005;Wang et al., 2009). In India most of the studies are focused on heavy metal contamination in water bodies and soil. Studies on heavy metal levels in the plants from polluted environments are limited. The data on the effects of pollution on the plant is lacking. Chatterjee and Banerjee (1999) reported $\mathrm{Zn}, \mathrm{Ni}, \mathrm{Cd}, \mathrm{Cu}$ and $\mathrm{Pb}$ contamination at $159,42,3.12,44$ and $536 \mathrm{ppm}$ respectively in roadside plants from residential areas of Calcutta. In the present study was made for comparative assessment of heavy metals contamination levels of $\mathrm{Zn}, \mathrm{Cu}, \mathrm{Cr}$ and $\mathrm{Pb}$ in six commonly growing plants viz. Ocimumsanctum, Leucas aspera, Lantana camara, Vincarosea, Bougainvilleaspectabilis and Riccinuscommunis) to evaluate the effects of heavy metals on phytochemicalsby analysingtotal protein content, proline content and gallic acid in the plants ii ) to evaluatethe oxidative stress by analyzing lipid peroxidation and antioxidant capacity of plants by analyzing catalase activity iii) To understand the impact of pollution on plants, correlation of phytochemicals level, lipid peroxidation and antioxidant capacity with heavy metals by way of statistics to understand any relation of the factors influencing the plant defense.

\section{MATERIALS AND METHODS}

Study area: On the basis of Pollution control board (PCB), India, Zonal report (Table 1; KPSCB 2016) on air pollution levels in Bangalore, industrial area with known air pollution levels was identified for the present study during January 2017 to January 2018 period. Bangalore University Campus, Christ University Campus at Hosur road and Kumbalagudu area away from the industrial zone with relatively lesser pollution levels were selected as control sites. The coordinates of the area selected for the study is summarized in Fig.1.

Sample collection: Fresh leaves of $O$. sanctum, B.spectabilis, L. aspera, L.camara, and $V$.roseawere collected from polluted sites of industrial zones and corresponding residential areas. The industrial areas have been designated as Zone I and the residential areas have been designated as Zone II. To account for variation within plant, leaves were plucked randomly from upper, middle and lower branches of plants. Leaves from different branches were pooled into composite samples, placed in plastic bags, transported in ice pack and stored in refrigerator at $2-8^{\circ} \mathrm{C}$ until analysis.

Analysis of heavy metal in leaf samples: Plant leaves $(1 \mathrm{~g})$ were acid digested with $2.0 \mathrm{~mL}$ nitric acid and $1.0 \mathrm{~mL}$ of hydrochloric acid. Heavy metals $\mathrm{Zn}, \mathrm{Cu}, \mathrm{Cr}$ and $\mathrm{Pb}$ were determined using Inductively coupled plasma-Atomic emission spectroscopy (Teledyne Leeman labs, Prodigy 7) by USEPA method (1982). All the heavy metal standards were procured from Lobo Chemie, India. Zn was analyzed at $213.85 \mathrm{~nm}$ with axial plasma view. Copper, chromium and lead were analyzed with radial plasma view at $324.74,267.71$ and $220.35 \mathrm{~nm}$ respectively.

\section{Biochemical measurements}

Protein content: Protein content of leaves was determined according to Bradford (1976) using bovine serum albumin (BSA) as a standard. Leaves $(10 \% \mathrm{~W} / \mathrm{V})$ was homogenized with phosphate buffer saline $(\mathrm{pH} 7.0)$ and centrifuged at $4000 \mathrm{rpm}$ for 10 minutes. Homogenate $(100 \mu \mathrm{L})$ was treated with Bradford reagent $(900 \mu \mathrm{L})$ and incubated at room temperature for 5 minutes. Absorbance of reaction mixture was recorded at $590 \mathrm{~nm}$ in Spectrophotometer (Teledyne Leeman labs, Prodigy 7). A standard graph of BSA was prepared and used for estimating the total protein content in leaves.

Proline estimation: Proline content in the leaves was determined as described by Bates et al. (1973). In brief, $1 \mathrm{~g}$ of leaves were extracted with $10 \mathrm{ml}$ of sulphosalicylic acid (3\% W/V) and filtered through Whatman No. 1 filter paper. Filtrate $(2 \mathrm{~mL})$ was incubated with $2 \mathrm{ml}$ ninhydrin acid and $2 \mathrm{ml}$ of glacial acetic acid at $100^{\circ} \mathrm{C}$ for $1 \mathrm{~h}$. The reaction 
mixture was cooled on ice, extracted with toluene and absorbance was read at $520 \mathrm{~nm}$ using toluene as the blank. A standard graph was prepared with different concentration of proline. The proline content was expressed in $\mathrm{mg}$ proline per $\mathrm{g}$ fresh weight of leaves.

Gallic acid estimation by High-performance liquid chromatography: Methanolic extract of dried leaves of plants from polluted and control sites were analyzed for gallic acid content by reversed phase HPLC (RP-HPLC) separation. Shimadzu HPLC instrument (LC-20AT Shimadzu Corporation, Japan) equipped with Binary low pressure gradient pumps and dual wavelength ultraviolet detector was used. HPLC conditions were optimized for separation of gallic acid through Chromochemie C18 column $(250 \mathrm{~mm} \times$ $4.6 \mathrm{~mm}, 5 \mu \mathrm{m}$ ) with a mobile phase consisting of acetonitrile and methanol in the ratio of $60: 40 \% \mathrm{v} /$ v. set at a flow rate of $1.0 \mathrm{~mL} / \mathrm{min}$ column. Sample stock solution of $10 \mathrm{mg} / \mathrm{ml}$ was prepared, and 10 $\mu \mathrm{L}$ of samples or standard was injected and detected at $275 \mathrm{~nm}$. Identification and quantification of gallic acid was carried out by comparing with the retention time of compounds from sample extract and standard. Gallic acid was expressed as mg gallic acid per gram of dry weight of leaves.

Catalase activity: Catalase activity (CAT, EC 1.11.1.6) of plant leaves was determined according to the Aebi (1984) with minor modification. In this method the enzyme substrate, hydrogen peroxide $\left(\mathrm{H}_{2} \mathrm{O}_{2}\right)$, is used at $10 \mathrm{mM}$ concentration, due to higher Vmax of catalase, removal of $\mathrm{H}_{2} \mathrm{O}_{2}$ is higher wherein other $\mathrm{H}_{2} \mathrm{O}_{2}$ metabolizing enzyme such as glutathione peroxidase is completely saturated. Leaves $(1 \mathrm{~g})$ were extracted with $10 \mathrm{ml}$ ice cold 50mM PBS (pH 7.0), centrifuged at $5,000 \mathrm{~g}$ for $10 \mathrm{~min}$, and the homogenate was used for determination of catalase activity. Enzyme activity was initiated with addition of $100 \mu \mathrm{L}$ of leaf extract to $900 \mu \mathrm{L}$ of $\mathrm{PBS}$ containing $10 \mathrm{mM} \mathrm{H}_{2} \mathrm{O}_{2}$. The rate of $\mathrm{H}_{2} \mathrm{O}_{2}$ reduction was monitored for 5 minutes with measurement of absorbance at $240 \mathrm{~nm}$. Hydrogen peroxide reduction was calculated using extinction coefficient 43.6. Catalase activity was defined as $\mu$ moles of $\mathrm{H}_{2} \mathrm{O}_{2}$ degraded per minute and expressed as $\mathrm{mU}$ per gram of fresh weight of leaves (Aebi, 1984).

Lipid peroxidation: Lipid peroxidation was determined as described by Draper and Hadley (1990) with minor modifications. The method is based on the measurement of thiobarituric acid-reactive substances (TBARS) formed when malonaldehyde, a marker of oxidative stress is reacted with TBA. Leaf $(1 \mathrm{~g})$ was extracted with $5 \mathrm{ml}$ of $15 \%$ trichloroacetic acid (v/v) and centrifuged at $10,000 \mathrm{~g}$ for 10 $\mathrm{min}$. The homogenate was incubated with $0.67 \%$ TBA (w/v) for $30 \mathrm{~min}$ at $100^{\circ} \mathrm{C}$. The reaction mixture is allowed to cool and absorbance was read at $535 \mathrm{~nm}$. The concentration of malonyldialdehyde (MDA) was calculated by the absorbance coefficient of MDA-TBA complex $1.56 \times 10^{5} \mathrm{~cm}^{-1} \mathrm{M}^{-1} \mathrm{~A}$ standard plot generated with different concentration of MDA was used for determining the MDA content in leaves. The results were expressed as nanomoles of MDA per milligram of leaves.

Statistical analysis: Data are presented as mean \pm SD. Statistical significance between means of different parameters in leaves from polluted and control sites were analyzed using the Student's ttest, considering $p<0.05$ as significant. Correlation coefficient of heavy metal content with phytochemicals, catalase activity and lipid peroxidation was determined by Pearson's correlation using Microsoft Excel 2013.

\section{RESULTS AND DISCUSSION}

Heavy metal analysis: Mean heavy metal concentrations in plant leaves from polluted (Zone I, Fig. $1 \mathrm{~A}$ ) and control sites (Zone II, Fig. 2 B)) are summarized in Table 3. As compared to plants from non polluted control sites, the plants from polluted sites showed elevation of all the heavy metals. Mean $\mathrm{Zn}$ levels in leaves from polluted sites was $45.49 \pm 31.44 \mathrm{ppm}$ compared to $37.21 \pm 29.51 \mathrm{ppm}$ observed in leaves from control sites. Species specific variation in accumulation of different heavy metals was observed among the plants. In the polluted sites highest Zinc levels at $105.51 \mathrm{ppm}$ were recorded in O. sanctum and lowest accumulation of $18.95 \mathrm{ppm}$ was recorded in $L$. camara (Fig. 2). In R. communis from polluted site

Table 1. Air pollution levels of selected regions for the study (Zone 1: Polluted and Zone 2: Non polluted).

\begin{tabular}{lllllllll}
\hline \multirow{2}{*}{ Zone I } & \multicolumn{7}{l}{ Particulate Matter (PM) } & \multicolumn{7}{l}{ Pollutants $\left(\mathbf{m g} / \mathbf{~ m}^{\mathbf{3}}\right.$ ) } & & \multirow{2}{*}{ AQI } \\
\cline { 2 - 8 } & $\mathbf{P M 1 0}$ & $\mathbf{P M 2 . 5}$ & $\mathbf{S O}_{2}$ & $\mathbf{N O}_{2}$ & $\mathbf{C O}$ & $\mathbf{N H}_{3}$ & $\mathbf{O}_{3}$ & \\
\hline Mysore road & 96 & 78 & 3 & 49 & 0 & 18 & $*$ & 96 \\
Hosur road (Koramangala) & 127 & 87 & 3 & 50 & 0 & 18 & $*$ & 127 \\
Peenya & 104 & 83 & 3 & 44 & 0 & 18 & $*$ & 104 \\
Yeshwanthpura & 86 & 75 & 3 & 49 & 0 & 17 & $*$ & 86 \\
K.R Market & 100.7 & $*$ & 7.5 & 52 & 0 & $*$ & $*$ & 101 \\
\hline Zone 2 & & & & & & & & \\
\hline Mysore road (Jna Bharathi campus) & 25 & $*$ & 4 & 11 & $*$ & $*$ & $*$ & 25 \\
Kumbalagodu (CHRIST University-11) & 50.4 & $*$ & 2.2 & 24 & $*$ & $*$ & $*$ & 50 \\
Hosur road (CHRIST University-1) & 65.6 & 30.4 & 2 & 31.9 & $*$ & 32 & $*$ & 66 \\
\hline
\end{tabular}

Source: (KSPCB, 2016) * Indicates Not determined. 
Table 2. Coordinates of selected zones of Bangalore city for study.

\begin{tabular}{llll}
\hline Zones & Area/Location & Sampling site & Coordinates \\
\hline & Mysore road & Amco Batteries & $12.965407,77.586727$ \\
\multirow{2}{*}{$\begin{array}{l}\text { Polluted regions } \\
\text { (Zone I) }\end{array}$} & Yeswanthapur & M/s Graphite India & $12.972112,77.574223$ \\
& Koramangala & Yeswanthapura industrial Area & $13.031906,77.542408$ \\
& K R Market & KHB industrial Area & $12.944867,77.603425$ \\
\multirow{2}{*}{$\begin{array}{l}\text { Non polluted } \\
\text { regions (Zone II) }\end{array}$} & Keenya & Victoria Hospital & $12.962839,77.574682$ \\
& Kumbalagudu & Peenya Industrial Area III phase & $13.035866,77.519007$ \\
& Jnabharathi-Mysore road & Christ Deemed University campus & $12.860814,77.437188$ \\
& & Christ Deemed university campus & $12.933533,77.604975$ \\
\end{tabular}

Table 3. Concentrations of Heavy metals in plant leaves from polluted and control sites.

\begin{tabular}{|c|c|c|c|c|c|c|c|}
\hline \multirow{3}{*}{$\begin{array}{l}\text { Heavy metals } \\
\mathrm{Zn}(\mathrm{ppm})\end{array}$} & \multicolumn{7}{|c|}{ Plant source } \\
\hline & \multicolumn{3}{|c|}{ Control sites (Residential areas) } & \multicolumn{4}{|c|}{ Polluted sites (Industrial areas } \\
\hline & 37.21 & \pm & 29.51 & 45.49 & \pm & 31.44 & \\
\hline $\mathrm{Pb}(\mathrm{ppm})$ & 13.54 & \pm & 6.19 & 20.99 & \pm & 8.86 & \\
\hline $\mathrm{Cu}(\mathrm{ppm})$ & 2.94 & \pm & 3.21 & 4.30 & \pm & 3.27 & \\
\hline $\mathrm{Cr}(\mathrm{ppm})$ & 1.84 & \pm & 1.99 & 2.54 & \pm & 1.95 & \\
\hline Heavy metals & \multicolumn{2}{|r|}{ Cr (ppm) } & Cu (ppm) & \multicolumn{2}{|c|}{ Zn (ppm) } & & $\mathrm{Pb}$ (ppm) \\
\hline MPL in soil & \multicolumn{2}{|r|}{$100^{*}$} & $100^{*}$ & \multicolumn{2}{|c|}{$300^{*}$} & & $100^{*}$ \\
\hline MPL in plants & \multicolumn{2}{|r|}{$1.30^{* *}$} & $73^{*}$ & \multicolumn{2}{|c|}{$100^{*}$} & & $0.30 *$ \\
\hline
\end{tabular}

Source: *- Chiroma et al (2014): ** WHO 1996

Table 4. Effect of air pollution on photochemical and antioxidant levels in plant leaves.

\begin{tabular}{lllllll}
\hline \multirow{2}{*}{ Study parameters } & \multicolumn{7}{c}{ Plant source } \\
\cline { 2 - 7 } & \multicolumn{1}{c}{ Control } & (Residential areas) & \multicolumn{3}{c}{ Polluted (Industrail area } \\
\hline Total protein $(\mathrm{mg} / \mathrm{g})$ & 8.35 & \pm & 1.27 & 6.57 & \pm & 1.71 \\
Gallic acid $(\mathrm{mg} / \mathrm{g})$ & 22.95 & \pm & 25.66 & 15.79 & \pm & 22.51 \\
Proline $(\mathrm{mg} / \mathrm{g})$ & 2.63 & \pm & 0.66 & 3.11 & \pm & 0.46 \\
Malonaldehyde $(\mathrm{nmol} / \mathrm{g})$ & 16.62 & \pm & 13.49 & 19.07 & \pm & 13.86 \\
Catalase activity $(\mathrm{mU} / \mathrm{g})$ & 78.94 & \pm & 15.24 & 66.72 & \pm & 17.95 \\
\hline
\end{tabular}

Table 5. Correlation of heavy metal with phytochemicals, catalase activity and lipid peroxidation in plants from control (Zone 2) sites.

\begin{tabular}{|c|c|c|c|c|c|c|}
\hline Metal & Total protein $(\mathrm{mg} / \mathrm{g})$ & Gallic acid $(\mathrm{mg} / \mathrm{g})$ & $\begin{array}{l}\text { Proline } \\
(\mathrm{mg} / \mathrm{g})\end{array}$ & $\begin{array}{l}\text { Catalase } \\
(\mathrm{mU} / \mathrm{g})\end{array}$ & activity & $\begin{array}{l}\text { MDA } \\
\text { (nmol/g) }\end{array}$ \\
\hline $\mathrm{Zn}$ & 0.279 & $0.871^{*}$ & -0.726 & -0.272 & & 0.054 \\
\hline $\mathrm{Pb}$ & -0.629 & -0.113 & -0.027 & -0.540 & & 0.253 \\
\hline $\mathrm{Cu}$ & $-0.846^{*}$ & -0.320 & -0.285 & -0.051 & & $0.961^{* *}$ \\
\hline $\mathrm{Cr}$ & $-0.943^{* *}$ & -0.331 & 0.020 & 0.098 & & 0.792 \\
\hline
\end{tabular}

*and ${ }^{* *}$ - indicates statistically significant correlation at $\mathrm{P}<0.05$ and $\mathrm{P}<0.005$ respectively

Table 6. Correlation of heavy metal with phytochemicals, Catalase activity and lipid peroxidation in plants from polluted (Zone 1)sites.

\begin{tabular}{llllll}
\hline Metals & $\begin{array}{l}\text { Total protein }(\mathbf{m g} / \\
\mathbf{g})\end{array}$ & Gallic acid $(\mathbf{m g} / \mathbf{g})$ & $\begin{array}{l}\text { Proline } \\
(\mathbf{m g} / \mathbf{g})\end{array}$ & $\begin{array}{l}\text { Catalase activity } \\
(\mathbf{m U} / \mathbf{g})\end{array}$ & $\begin{array}{l}\text { MDA } \\
(\mathbf{n m o l} / \mathbf{g})\end{array}$ \\
\hline $\mathrm{Zn}$ & -0.365 & $0.937^{*}$ & 0.137 & -0.121 & -0.053 \\
$\mathrm{~Pb}$ & -0.628 & -0.318 & -0.315 & -0.127 & 0.425 \\
$\mathrm{Cu}$ & -0.527 & -0.232 & -0.562 & 0.221 & $0.881^{*}$ \\
$\mathrm{Cr}$ & -0.665 & -0.128 & -0.365 & 0.178 & 0.758 \\
\hline
\end{tabular}

*and**- indicates statistically significant correlation at $\mathrm{P}<0.05$ and $\mathrm{P}<0.005$ respectively

highest accumulation of $\mathrm{Pb}, \mathrm{Cu}$ and $\mathrm{Cr}$ at 28.95, 10.25 and 5.68 ppm respectively was recorded. In L.camara lowest accumulation of all the heavy metals was observed (Figs. 2 to 5).

Heavy metal levels in the leaves depict the net environmental pollution constituting the metals deposited from air and absorbed from the soil or water. In the present study the levels of $\mathrm{Cu}$ and
$\mathrm{Zn}$ in the leaves were within the permissible limits stipulated by WHO (Chiroma et al., 2014; WHO, 1996). The levels of $\mathrm{Pb}$ and $\mathrm{Cr}$ were above the permissible limits of $\mathrm{WHO}$ for leafy vegetables. Heavy metal concentrations found in plant leaves was in following descending order: $\mathrm{Zn}>\mathrm{Pb}>\mathrm{Cu}>\mathrm{Cr}$. Review on metal toxicity in plants by solution culture indicates the toxicity of metals will follow the 

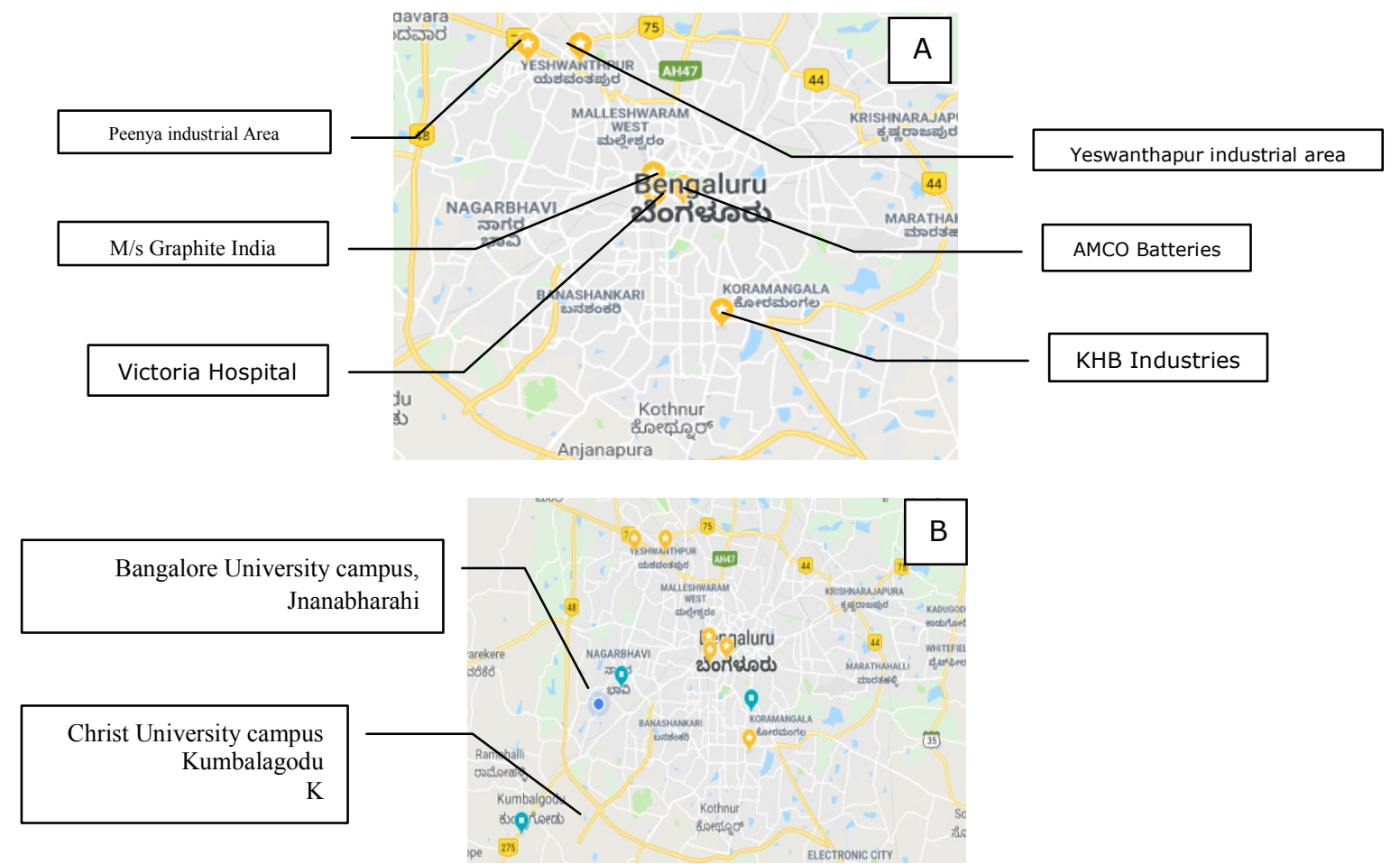

Fig. 1. Map of polluted sites $(A)$ and non-polluted control sites (B) selected for the study.

trend $\mathrm{Pb} \approx \mathrm{Hg}>\mathrm{Cu}>\mathrm{Cd} \approx \mathrm{As}>\mathrm{Co} \approx \mathrm{Ni} \approx \mathrm{Zn}>\mathrm{Mn}$, with median toxic concentrations of $0.30 \mu \mathrm{M}(\mathrm{Pb})$, $0.47 \mu \mathrm{M}(\mathrm{Hg}), 2.0 \mu \mathrm{M}(\mathrm{Cu}), 5.0 \mu \mathrm{M}(\mathrm{Cd}), 9.0 \mu \mathrm{M}$

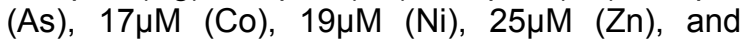

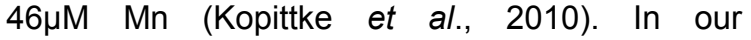

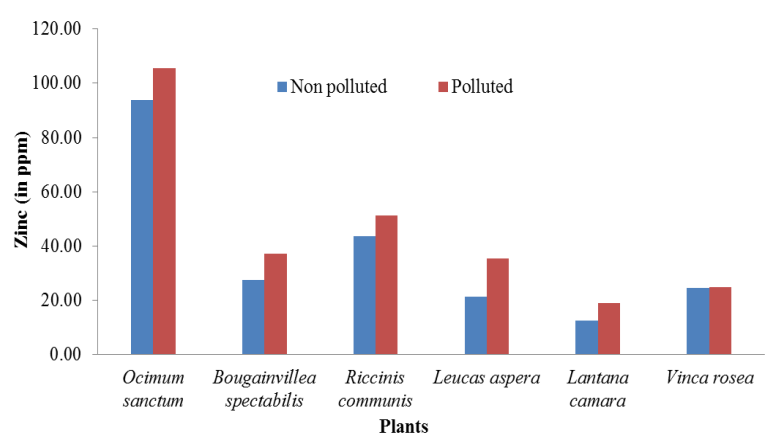

Fig. 2. Zinc levels in plant leaves collected from polluted (Zone I and control (Zone 2) sites.

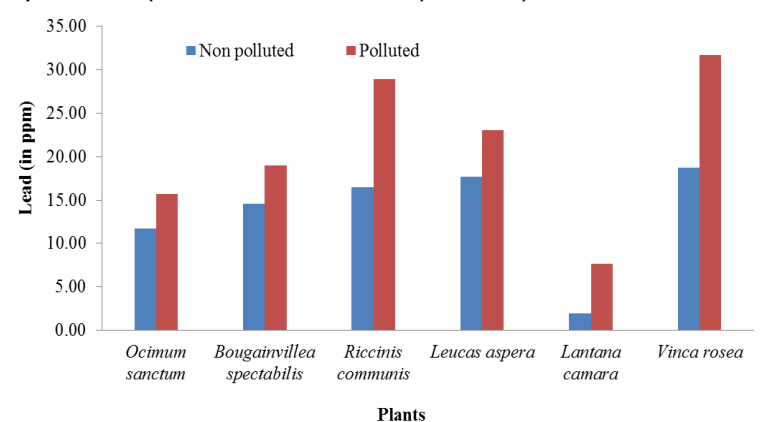

Fig. 4. Lead levels in plant leaves collected from polluted (Zone 1)and control (Zone 2)sites. study,levels of $\mathrm{Zn}$ and $\mathrm{Cu}$ were below the critical toxicity level of 100-300 ppm and 20-30ppm respectively (Hodson, 2012). Zn and $\mathrm{Cu}$ at lower concentration work as micronutrients and become toxic at only higher doses. Lead accumulation was

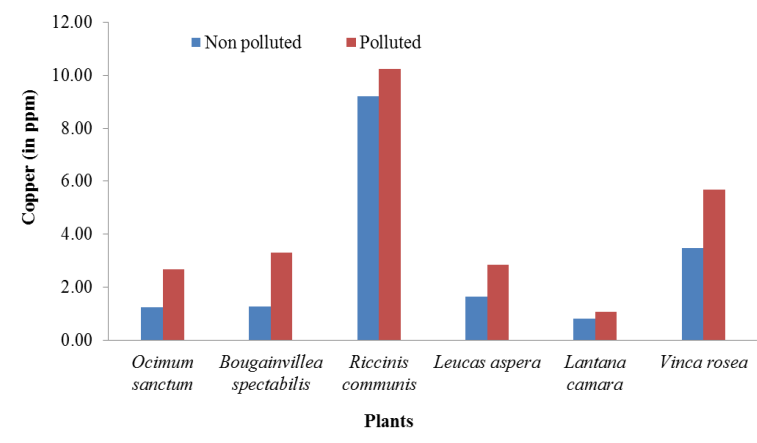

Fig. 3. Copper levels in plant leaves collected from polluted (Zone I) and control (Zone 2) sites.

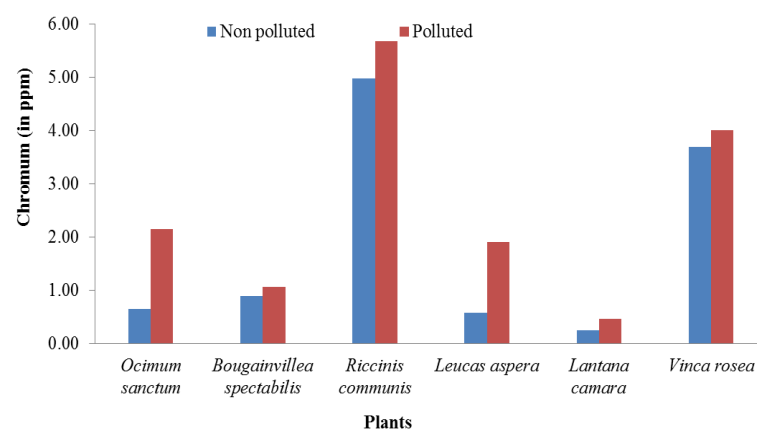

Fig.5. Chromium levels in plant leaves collected from polluted (Zone I) and control (Zone 2)sites 


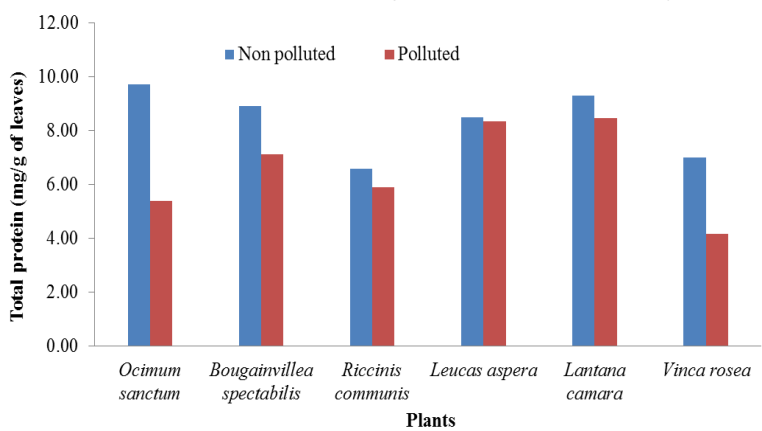

Fig.6. Total protein in plant leaves collected from polluted (Zone I) and control (Zone 2) sites.

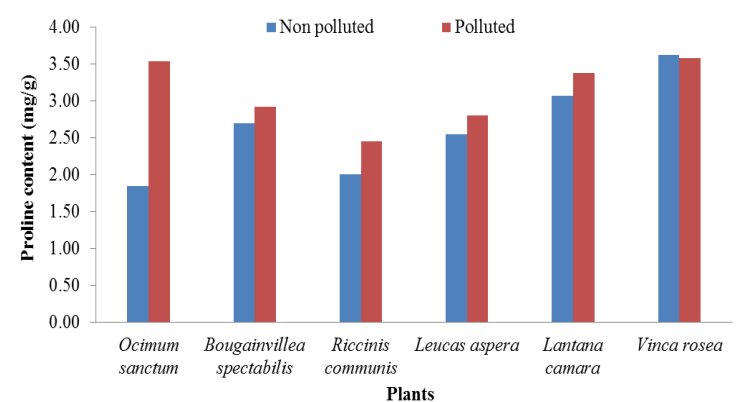

Fig. 7. Proline content in plant leaves collected from polluted (Zone I) and control (Zone 2) sites.

above the critical toxicity levels of $0.6-28 p p m$. Mean chromium levels in polluted sites were elevated and found at a critical toxicity levels to plants at $100 \mu \mathrm{M}(2.4 \mathrm{ppm}$, Shanker, et al., 2005). Harish (2012) provided an account of current and projected vehicular density in Bangalore city and associated health risk due to the environmental pollution. Lead constitutes an important air pollutant causing many deleterious health effects associated with automotive exhaust worldwide that deposit on plant with the particulate matter and contaminate the soil in the polluted environment (Li, 2012).

A study conducted to assess the heavy metal contamination in water bodies, soil and vegetables at Bangalore during year 2005-2008 revealed the elevated levels contamination of $\mathrm{Cd}, \mathrm{Pb}, \mathrm{Cr}$ and $\mathrm{Ni}$, higher than safe prescribed limit of $0.1,0.5$, 0.1 and $0.2 \mathrm{ppm}$ respectively for vegetables (Varalakshmi and Ganeshmurthy, 2010). When compared to water and soil, comparatively higher (10-100 fold) heavy metal contamination was reported in vegetables indicating accumulation of heavy metals in the fruits and leaves of plants. In our study, the $\mathrm{Pb}$ and $\mathrm{Cr}$ contamination levels were relatively higher than the $\mathrm{Pb}(1-7 \mathrm{ppm})$ and $\mathrm{Cr}$ (2-12ppm) levels reported by Varalakshmi and Ganeshmurthy (2010). Wei et al. (2017) reported $\mathrm{Cd}$ and $\mathrm{Cr}$ contamination ranging from 0.25-2.5 $\mathrm{ppm}$ and $0.1-0.4 \mathrm{ppm}$ respectively in tubers collected from local markets of Bangalore. In our study, mean $\mathrm{Cr}$ levels of observed in roadside plants agrees with the report of Swati et al.

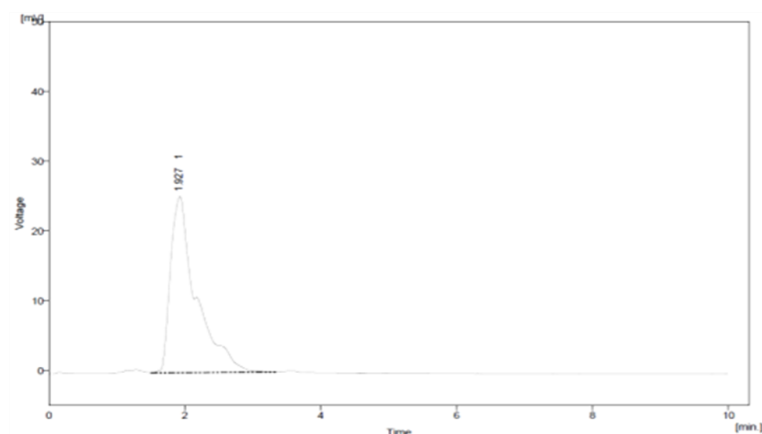

Fig. 8. HPLC chromatogram of Gallic acid standard.

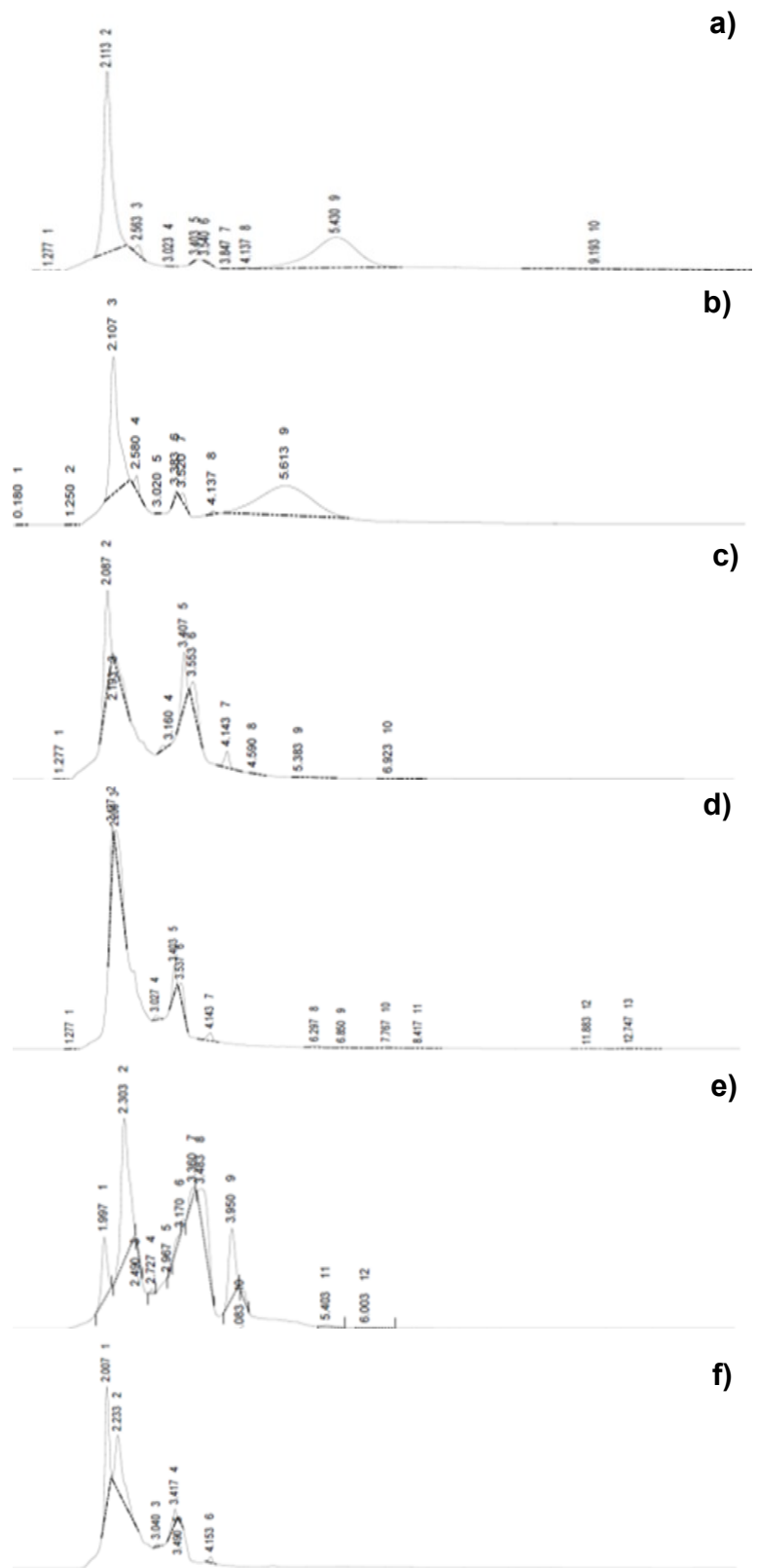

Fig. 9. HPLC chromatogram of Leaf extract from polluted sites (Zone I).

a) O.sanctum, b) B.spectabilis, c) R.communis; d) L. aspera: e) L.camara; f) V. rosea 
Manjunath, B.T. and Reddy, J. / J. Appl. \& Nat. Sci. 11(1): 66 - 75 (2019)

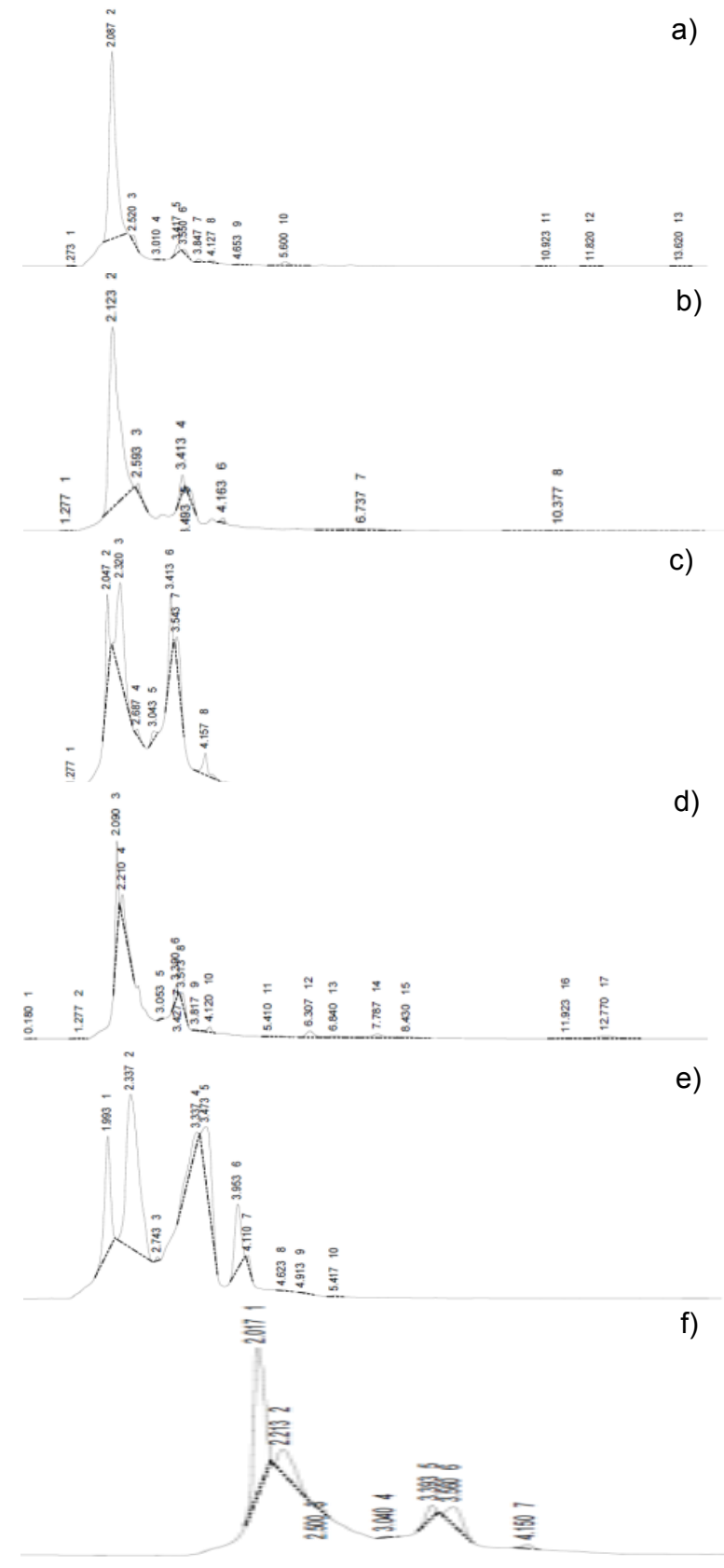

Fig.10. HPLC chromatogram of Leaf extract from Non Polluted (Zone 2) sites.

A) O.sanctum, b) B.spectabilis, c) R.communis; d) L. aspera: e) L.camara; f) V. rosea.

(2018). Increase in levels of heavy metals in vegetation is an indication of net air pollution in the environment. The higher $\mathrm{Pb}$ and $\mathrm{Cr}$ content recorded in the present study is cause for concern and needs remedial measures to bring down their levels to safe levels.

\section{Biochemical analysis}

Protein content: Mean total protein content in plant leaves from polluted (Zone 1) sites was reduced at $6.57 \pm 1.71 \mathrm{mg} / \mathrm{g}$ compared to $8.35 \pm 1.27$ $\mathrm{mg} / \mathrm{g}$ observed in leaves from control (Zone 2)

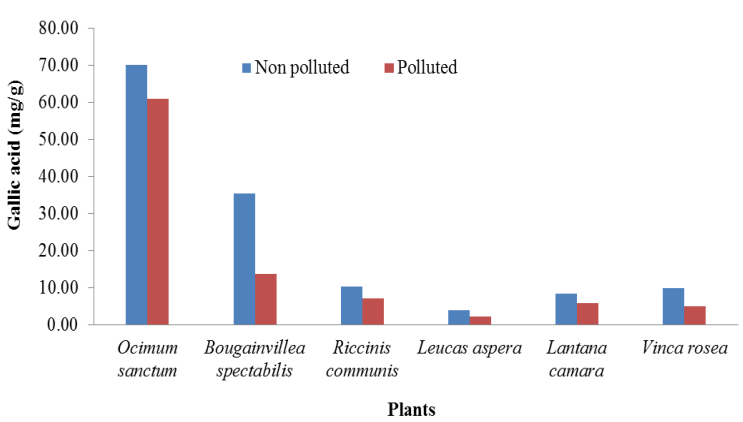

Fig.11. Gallic acid content in plant leaves collected from polluted(Zone 1) and control (Zone 2) sites.

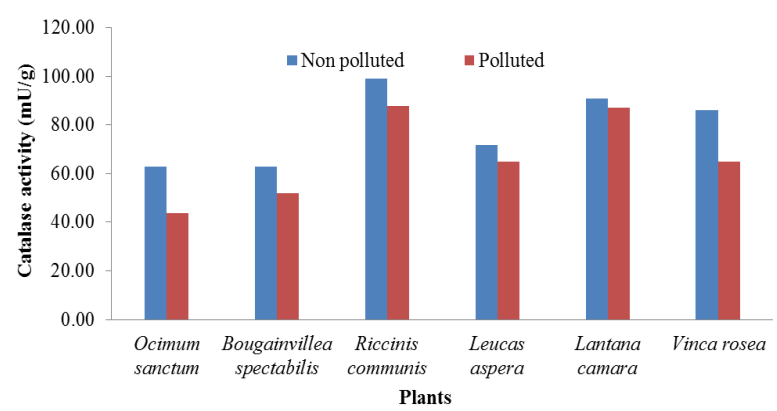

Fig. 12. Catalase activity in plant leaves collected from polluted (Zone I) and control (Zone 2) sites.

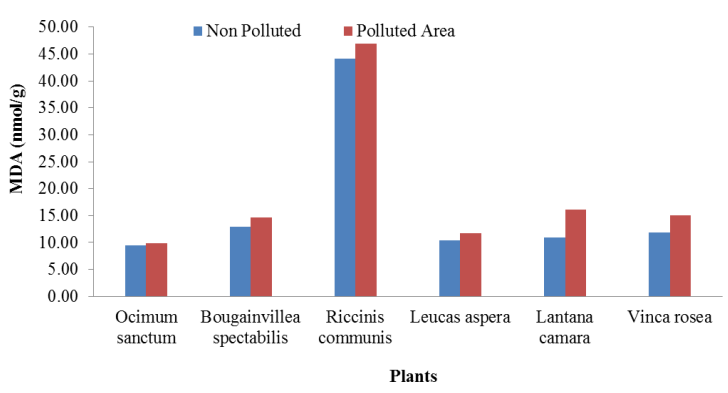

Fig. 13. Malonaldehyde (MDA) content in plant leaves collected from polluted (Zone 2)and control (Zone 2) sites.

sites (Table 4). Compared to control sites in the polluted sites (Fig. 6), highest reduction in total protein content was observed in $O$. sanctum (5.40 $\mathrm{v} / \mathrm{s} 9.73 \mathrm{mg} / \mathrm{g}$ ) and Vincarosea (4.19v/s $7.01 \mathrm{mg} / \mathrm{g}$ ). Total soluble protein levels are an indication of the physiological status of plants. Effect of different heavy metal on protein levels cannot be generalized. $\mathrm{Zn}$ is known to decrease protein content and corresponding rise in activity of protease as a response to heavy metal toxicity (Pena et al., 2008). ROS led fragmentation of total protein Davies et al (1987) and accumulation of amino acids (Chen et al., 2001) has been reported in plants. In our study the total protein content was reduced. Further work on the levels of enzymes involved in key metabolic pathway should give more insights on the stress response in plants. Tables 5 and 6 present the correlation analysis between the heavy metals and the protein content at control and pol- 
luted sites, respectively.

Proline content: Mean proline content in plant leaves from polluted sites was elevated at $3.11 \pm 0.46 \mathrm{mg} / \mathrm{g}$ compared to $2.63 \pm 0.66 \mathrm{mg} / \mathrm{g}$ observed in leaves from control sites (Table 4). There was an increase in proline content in all the leaves from polluted sites. Compared to control sites, in the polluted sites (Fig. 7), highest increase in proline content was observed in 0 . sanctum (3.54 v/s $1.85 \mathrm{mg} / \mathrm{g})$.

Accumulation of proline under heavy metals and other oxidative stress is well studied in plants (Hare and Cress, 1997).Proline provides plants protection against heavy metal induced oxidative stress by acting as a metal chelator and osmoprotectant. Proline scavenges the free radicals, maintains the intracellular redox potential that helps in stabilizing the protein conformation and membrane potential thereby enhance the tolerance potential of plants by regulating water potential which is impaired by heavy metals. In our study, proline levels were comparative enhanced in plants from polluted sites indicating stress from the polluted environment. Tables 3 and 4 present the correlation analysis between the heavy metals and the phytochemicals at control and polluted sites, respectively. Correlation of metal with proline content showed a negative correlation with $\mathrm{Pb}$ $(r=-0.315), \quad \mathrm{Cu}(r=-0.562)$ and $\mathrm{Cr}(r=-0.365)$ in plants from polluted sites. While $\mathrm{Cr}$ and $\mathrm{Zn}$ showed positive correlation with proline content in control sites ( $r=0.020)$ and polluted sites $(r=0.137)$ respectively. Analysis with larger number of plants should provide valuable information regarding the relationship of proline content with heavy metal stress in the environmental conditions.

Gallic acid analysis: HPLC chromatogram of standard gallic acid showed peak at retention time of $1.92 \mathrm{~min}$ (Fig. 8). HPLC chromatograms of plants from Zone I and Zone II are shown in Fig. 9 and Fig. 10 respectively. Mean gallic acid content in plant leaves from polluted sites was decreased at $15.79 \pm 22.51 \mathrm{mg} / \mathrm{g}$ compared to $22.95 \pm 25.66$ $\mathrm{mg} / \mathrm{g}$ observed in leaves from control sites (Table 3 ). There was a decrease in gallic acid content in all the leaves from polluted sites. Compared to control sites, in the polluted sites (Fig. 11), higher decrease in gallic acid content was observed in $B$. spectabilis $(13.63 \mathrm{v} / \mathrm{s} 35.41 \mathrm{mg} / \mathrm{g}, \mathrm{P}<0.005)$ and Vincarosea(4.90 v/s $9.79 \mathrm{mg} / \mathrm{g})$.

Plants have plethora of phenolic secondary metabolites that functions as antioxidant systems to counter the effects of various biotic and abiotic stress. Stimulation of secondary metabolite production with different stress has been hypothesized to occur due to activation of gene expression of several secondary metabolite pathways through signaling by oxylipins (Axel, et al., 2004).Monicaet al (2010) studied the stress response of plants under sulfate stress and correlat- ed the elevated levels of total phenolic compounds with water stress rather than the sulfate ions from gypsum habitat. In our study there was no statistically significant difference in gallic acid content in plants from polluted sites and control sites. However statistically significant correlation with $\mathrm{Zn}$ levels was observed in plants from both control $(r=0.871, \quad P<0.05)$ and polluted sites $(r=0.937, P<0.05)$ (Tables 3 and 4 respectively). Zinc is an important micronutrient which is involved many physiological process (Broadley, et al., 2007) and has been linked with metabolism involving carbohydrates, lipids and nucleic acids at lower concentrations. Further control studies needs to carried out to understand the effects of Zinc on synthesis of secondary metabolites. Gallic acid is a potent antioxidant and has been reported to possess good chelating ability of $\mathrm{Cu}, \mathrm{Zn}, \mathrm{Cd}$ and $\mathrm{Ni}$ from soil without increasing the risk of leachates (C .W. A. do Nascimento et al., 2006). Akanksha et al. (2017) reported enhancement of antioxidant defense through enhancement of total flavanoids content, reducing power and reduction of reactive oxygen species in Oryza sativa grown in seeds primed with gallic acid and rutin (10$60 \mu \mathrm{g} / \mathrm{mL}$ ). Phytochemicals analysis of total phenolic and flavanoids under oxidative stress could be used as biochemical markers of stress response or tolerance to heavy metals.

Catalase activity: Mean catalase activity in plant leaves from polluted sites was decreased at 66.72 $\pm 17.95 \mathrm{mU} / \mathrm{g}$ compared to $78.94 \pm 15.24 \mathrm{mU} / \mathrm{g}$ observed in leaves from control sites (Table 4). There was a decrease in catalase activity in all the leaves from polluted sites (Fig. 12). Compared to control sites, in the polluted sites, higher decrease in catalase activity was observed in $O$. sancutum $(43.82 \mathrm{v} / \mathrm{s} 62.92 \mathrm{mU} / \mathrm{g})$ and Vincarosea $(64.84 \mathrm{v} / \mathrm{s}$ $85.98 \mathrm{mU} / \mathrm{g}$ ).

Enzymatic and non-enzymatic antioxidant defense system in plants effectively neutralizes the ROS overproduction induced by heavy metals. Several studies have revealed an elevated level of catalase activity in plant exposed to heavy metals. In our study, even though there was an increased heavy metal concentration the catalase activity was decreased in leaves from polluted sites. Tables 5 and 6 present the correlation analysis between the heavy metals and the catalase activities at control and polluted sites, respectively. Pearson's correlation analysis revealed a negative correlation with $\mathrm{Pb}$ and $\mathrm{Zn}$ content in control $(\mathrm{Pb}, \mathrm{r}=-$ $0.540 ; \mathrm{Zn}, r=-0.272)$ and polluted sites $(\mathrm{Pb}, \mathrm{r}=$ $0.127 ; \mathrm{Zn}, \mathrm{r}=-0.121)$. It is difficult to identify the factors involved in the stress response in samples drawn from field conditions. Controlled studies with the selected plants provide better insights into the effect of metal on the levels of antioxidant enzymes.

Lipid Peroxidation: Mean Lipid peroxidation lev- 
els as measured by MDA levels in plant leaves from polluted sites was increased at $19.07 \pm 13.86$ $\mathrm{mU} / \mathrm{g}$ compared to $16.62 \pm 13.49 \mathrm{mU} / \mathrm{g}$ observed in leaves from control sites (Table 4). There was an increase in MDA levels in all the leaves from polluted sites (Fig. 13). Compared to control sites, in the polluted sites, higher increase in lipid peroxidation was observed in L. camara (MDA $16.16 \mathrm{v} /$ s $10.99 \mathrm{nmol} / \mathrm{g})$ and Vincarosea (15.10 v/s 11.80 $\mathrm{nmol} / \mathrm{g})$.

Heavy metal exposure is known to induce oxidative stress in plants. In our study lipid peroxidation was comparatively increased in all collected from polluted plants. Tables 5 and 6 present the correlation analysis between the heavy metals and the lipid peroxidation at control and polluted sites, respectively. There was a statistically significant positive correlation of MDA levels with $\mathrm{Cu}$ in both polluted $(r=0.961, P<0.005)$ and control sites. $(r=0.881, P<0.05)$. $\mathrm{Cr}$ and $\mathrm{Pb}$ levels showed positive correlation with MDA levels ( $r=0.792$ in polluted; $r=0.758$ in control sites) and $\mathrm{Pb}(r=0.425$ in polluted; $r=0.253$ in control sites).

\section{Conclusion}

In the present study, there were clear comparatively elevated levels of heavy metals in plants from polluted environments. Levels of $\mathrm{Pb}$ and $\mathrm{Cr}$ were higher than the threshold levels of toxicity to plants and humans. Plants studied in the present study O.sanctum, L.aspera, L.camara, V. rosea, $B$. spectabilisand R.communisshowed elevated levels of MDA content from polluted environment indicating lipid peroxidation due to oxidative stress. The plants varied in biochemical response to stress induced by the heavy metals. Phytochemicals analysis revealed that plants in polluted environment have been under stress as revealed by comparatively higher proline levels, which is an indicator of oxidative stress. Oxidative stress was evident as assessed by decreased catalase activity and increased Lipid peroxidation levels. Levels of Total protein and gallic acid were decreased in response to stress. Among the heavy metals only Cu showed statistically significant positive correlation with lipid peroxidation in leaves of plants from both control and polluted sites. Further research on response of these common thriving plants to different levels of pollutants under controlled environment would provide greater insights in using them as green cover in urban environment to mitigate the effects of pollutants.

\section{REFERENCES}

1. Aebi H. (1984). Catalase in vitro. Methods in Enzymology. 105:121-126.

2. Akanksha,S., Rupali G., and Rakesh P. (2017). Exogenous application of rutin and gallic acid regulate antioxidants and alleviate reactive oxygen generation in Oryza sativa L. Physiol Mol Biol Plants. 23(2): 301 -309 .
3. Axel, M., Birgit, S., and Wilhelm, B. (2004). Biotic and heavy metal stress response in plants: evidence for common signals. FEBS Letters.566 (1-3), pp 1-5.

4. Bates, L.S., R.P. Waldren and I.D. Tear (1975). Rapid determination of free proline for water stress studies. Plant and Soil. 39: 205-207.

5. Bradford, M. M. (1976). A rapid and sensitive method for the quantitation of microgram quantities of protein utilizing the principle of protein-dye binding. Analytical biochemistry, 72(1-2), 248-254.

6. Broadley, M.R., P.J. White, J.P. Hammond, I. Zelko, A. Lux. (2007). Zinc in plant. New Phytol., 173: 677 702.

7. Chatterjee, A. and Banerjee, R.N. 1999. Determination of lead and other metals in a residential area of greater Calcutta. The Science of the Total Environment, 227: 175-185.

8. Chen, L.M., C.C. Linard, C.H. Kao. (2001). Copper toxicity in rice seedlings:changes in antioxidative enzyme activities, $\mathrm{H} 2 \mathrm{O} 2$ level and cell wall peroxidaseactivity in roots. Bot Bull AcadSinica, 41: 99-103.

9. Chiroma, T. M., Ebewele, R. O., \&Hymore, F. K. (2014). Comparative assessment of heavy metal levels in soil, vegetables and urban grey waste water used for irrigation in Yola and Kano. International Refereed Journal of Engineering and Science, 3(2), 1 $-9$.

10.Davies, K.J.A. (1987). Protein damage and degradation by oxygen radicals. I.General aspects. J Biochem Chem., 262: 9895-9901.

11.Draper HH and Hadley M. (1990) Methods Enzymol. 1990;186:421-31. Malondialdehyde determination as index of lipid peroxidation. Soil, 39: 205-207.

12. Harish M. (2012). A study on air pollution by automobiles in Bangalore city. Management research and practice Vol. 4 Issue 3 pp: 25-36.

13. Hodson M-J. (2012) Metals in action, Biochemical Society, oct 2012, 28-32.

14.Karntaka State Pollution control board (2016). Annual reports https://www.kspcb.gov.in/ annual_reports.html

15.Kopittke PM, Blamey FP, Asher CJ, Menzies NW (2010). Trace metal phytotoxicity in solution culture: a review. Journal of Experimental Botany, Vol 61 (4), pp 945-954.

16.Li Qi, (2012) Lead pollution and its assessment of road side soils in Suzhou city, Advanced material research, 534, 235-238.

17.Monica B., María, S., Inmaculada B., Pilar, D., Antonio L. Josep L., Cristina L., Olga M., and Oscar v. (2010). Phenolic Compounds as Stress Markers in Plants from Gypsum Habitats. Bulletin UASVM Horticulture, 67(1), 44-49.

18. Nascimento C .W. A. do, DulaA., Baoshan X. (2006). Comparison of natural organic acids and synthetic chelatesat enhancing phytoexraction of metals from amultimetal contaminated soil. Environmental Pollution, 140, 114-123.

19.Pena, Liliana \&Zawoznik, Myriam \&Tomaro, María \& Gallego, Susana. (2008). Heavy metals effects on proteolytic system in sunflower leaves. Chemo$\begin{array}{llll}\text { sphere. } & 72 . & 741-6 . & 10.1016 /\end{array}$ j.chemosphere.2008.03.024.

20.Sayantan, D., and Shardendu. (2017). Phosphate amendments moderate the arsenate accumulation and its subsequent oxidative and physiological toxicities in Amaranthus viridisL. Proceedings of the Na- 
tional Academy of Sciences, India Section B: Biological Sciences. 87(4): 1343-1353.

21.Shanker, A.K., Cervantes, C., Loza-Tavera,H., and Avudainayagam,S.(2005). Chromium toxicity in plants. Environment International. 31: 739-753.

22.Swati, B., Guru Prasad, V., Tejeaswin, $M$ and Jessen, G. (2018). Assessment of heavy metal contamination in tubers sold in local markets of BangaIore, Karnataka, India. International Research Journal of Environmental Sciences, Vol. 7(8), 24-26.

23.Tiwari S, Agrawal M, Marshall FM. 2006. Evaluation of ambient air pollution impact on carrot plants at a suburban site using open top chambers. Environmental Monitoring and Assessment 119:15-30.

24.U.S. Environmental Protection Agency USEPA (1982). Inductively Coupled Plasma- Atomic Emission Spectrometric Method for Trace Element Analysis of Water and Wastes-Method 200.7, Dec. 1982. EPA-600/4-79-020, revised March 1983.

25.Varalakshmi, L.R And Ganeshamurthy A.N (2012). Heavy Metal Contamination Of Water Bodies, Soils And Vegetables In Peri Urban Areas- A Case Study In Bangalore. J. Hort. Sci.. 7(1):62-67.

26.Wang, F., B. Zeng, Z. Sun and C. Zhu (2009). Rela- tionship between proline and $\mathrm{Hg} 2+$-induced oxidative stress in a tolerant rice mutant. Arch Environ ContamToxicol, 56: 723-731.

27.Wei X, Lyu S, Yu Y, Wang Z, Liu H.Pan D and Chen, J. (2017). Phylloremediation of Air Pollutants: Exploiting the Potential of Plant Leaves and Leaf-Associated Microbes. Front. Plant Sci. 8:1318. doi: 10.3389/ fpls.2017.01318.

28.WHO (1996) Permissible limits of heavy metals in soil and plants (Geneva: World Health Organization), Switzerland.

29.WHO (2006). WHO Air Quality Guidelines for Particulate Matter, Ozone, Nitrogen Dioxide and Sulfur Dioxide. Geneva: WHO Press, World Health Organization.

30.Woo, S.Y., D.K. Lee and Y.K. Lee (2007). Net photosynthetic rate, ascorbate peroxidase and glutathione reductase activities of Erythrina orientalis in polluted and non-polluted areas. Photosynthetica. 45(2):293295

31.Woodward, A.J. and Bennettl.J. (2005). The effect of salt stress and abscisic acid on proline production, chlorophyll content and growth of in vitro propagated shoots of Eucalyptus camaldulensis. Plant Cell, Tissue and Organ Culture. 82: 189-200. 